\title{
Agro-morphological characterization and genetic divergence assessment in bush snap bean genotypes ${ }^{1}$
}

\author{
Daniela da Costa Vaz 2 , Odilon Peixoto de Morais Júnior ${ }^{3}$, Nei Peixoto ${ }^{4}$
}

\section{ABSTRACT}

The characterization and identification of genetically divergent parents for crosses are important tasks in snap bean breeding programs, for a greater availability of cultivars to growers. This study aimed at characterizing bush snap bean genotypes originating from different countries; assessing the genetic divergence between the genotypes and the genetic variability extent, concerning 12 agro-morphological traits; and determining the relative importance of these traits for the genetic divergence. The experiment was conducted in a randomized complete block design, with 29 genotypes and four replications. The UPGMA and Tocher optimization methods, both based on the generalized distance of Mahalanobis, and the canonical variables method were used to analyze the genetic divergence. The genotypes exhibited a wide range of genetic variability for the agro-morphological traits evaluated, mainly for 100-seed weight, aspect and yield of commercial pods, plant height at harvest and pod weight. A high genetic divergence was detected between the genotypes, in which the 100-seed weight and aspect of commercial pods were the most important traits for clustering. Some genotypes own desirable characteristics for these and other traits, given the favorable genetic associations between traits. The snap bean genotypes originated from different countries tended to cluster together, indicating that similar germplasm is shared among different countries, thus suggesting a strong trans-national seed exchange.

KEYWORDS: Phaseolus vulgaris; yield and aspect of commercial pods; genetic variability.

\section{INTRODUCTION}

Snap bean (Phaseolus vulgaris L.) is an important horticultural crop throughout the world. It is consumed in the form of immature seeds and pods and is a source of essential vitamins $\left(A, B_{12}\right.$

\section{RESUMO}

Caracterização agromorfológica e avaliação de divergência genética em genótipos de feijão-vagem arbustivo

A caracterização e a identificação de genitores geneticamente divergentes para cruzamentos são tarefas importantes em programas de melhoramento de feijão-vagem, para maior disponibilidade de cultivares aos produtores. Objetivou-se caracterizar genótipos de feijão-vagem arbustivo de diferentes países de origem; avaliar a divergência genética entre os genótipos e a extensão da variabilidade genética, em relação a 12 caracteres agro-morfológicos; e determinar a importância relativa desses caracteres para a divergência genética. O experimento foi conduzido em delineamento de blocos completos ao acaso, com 29 genótipos e quatro repetições. Para a análise de diversidade genética, foram empregados os métodos de otimização de Tocher e UPGMA, com base em distância generalizada de Mahalanobis, e o método de variáveis canônicas. Os genótipos apresentaram ampla variabilidade genética para os caracteres avaliados, principalmente para peso de 100 sementes, aspecto e rendimento de vagens comerciáveis, altura da planta na colheita e peso das vagens. Alta divergência genética foi detectada entre os genótipos, nos quais o peso de 100 sementes e o aspecto de vagens comerciáveis foram os caracteres mais importantes para o agrupamento. Alguns genótipos possuem características desejáveis para estes e outros caracteres, tendo-se em conta as associações genéticas favoráveis entre os mesmos. Os genótipos de feijão-vagem de diferentes países de origem tenderam a se agrupar, indicando que germoplasma semelhante é compartilhado entre diferentes países, sugerindo, assim, uma forte troca transnacional de sementes.

PALAVRAS-CHAVE: Phaseolus vulgaris; produtividade e aspecto de vagens comerciáveis; variabilidade genética.

and $\mathrm{C}$ ), minerals and dietary fiber, which make it an excellent component of the human nutrition (Filgueira 2013).

The primary center of origin and diversity for snap beans is believed to be the Americas, where various studies have suggested that most groups are

1. Manuscript received in Oct./2016 and accepted for publication in May/2017 (http://dx.doi.org/10.1590/1983-40632016v4743525).

2. Universidade do Estado de Mato Grosso, Departamento de Agronomia, Nova Mutum, MT, Brazil.

E-mail: daniela_gds2@hotmail.com.

3. Universidade Federal de Goiás, Escola de Agronomia, Departamento de Melhoramento de Plantas, Goiânia, GO, Brazil.

E-mail: odilonpmorais@gmail.com.

4. Universidade Estadual de Goiás, Departamento de Agronomia, Ipameri, GO, Brazil.E-mail: nei.peixoto48@gmail.com. 
derived from the Andean common bean genepool (Gepts et al. 1986). However, snap beans are widely distributed and very diverse around the world, especially in Europe and Asia (Blair et al. 2010).

While dry bean market classes are based on seed characteristics and horticultural traits, snap bean market classes are based on pod characteristics and plant type (Myers \& Baggett 1999). Snap beans comprise a group of common beans selected for succulent pods, with reduced fiber content $(<20 \%)$, and have a great economic and social importance in Brazil, being marketed throughout the year and produced almost exclusively in small family farms (Peixoto \& Cardoso 2016).

The selection pressure for snap bean pod characteristics has been intense, generating large phenotypic differences in snap bean types. Snap beans are also very diverse in growth habit and plant ideotype, ranging from type I (determinate) erect bush beans to type IV (indeterminate) climbing beans (Myers \& Baggett 1999). The majority of tropical cultivars are indeterminate climbing snap beans, while determinate erect bush beans prevail in temperate zones (Blair et al. 2010). In Brazil, for example, the main recommended snap bean cultivars are indeterminate-type crops, grown on trellises. However, cultivars with determined or bush growth not only dispense staking, but also grow earlier, so that the harvest can be concentrated in a short period of time. There are cultivars that allow a single harvest, lowering the exposure to biotic factors and allowing a mechanized production. Mechanization results in more rational land and labor use, thus reducing production costs and increasing the farmer income (Filgueira 2013, Peixoto \& Cardoso 2016).

For a greater availability and release of new bush snap bean cultivars that meet the demands of growers and consumers, efficient actions in breeding programs are necessary, including the introduction and evaluation of new germplasms, crosses among the best available parents, accurate selection of plants and progenies and, finally, the release of the superior lines as cultivars. The first steps in a snap bean breeding program are the characterization and genetic divergence assessment of candidate parents. This procedure allows an efficient management of the breeding germplasm and the definition of best crosses. Crosses between genetically divergent and complementary parents for multiple traits are an important strategy to achieve higher selection gains, given the larger genetic variability released by these crosses (Krause et al. 2009, Araújo et al. 2012).

When the phenotypic data of the parents is available, without any crosses information, the application of multivariate analysis techniques based on some measures of dissimilarity is recommended (Johnson \& Wichern 1992, Cruz et al. 2012). This procedure allows the evaluation of the genetic divergence among various genotypes, across several agro-morphological traits. There are several useful multivariate analysis techniques for predicting genetic divergence, such as clustering methods, either optimization or hierarchical, and canonical variable analysis. There are also some dissimilarity measurements, such as the average Euclidean distance and the Mahalanobis distance (Johnson \& Wichern 1992). These techniques allow the allocation of genotypes in groups, so that there is a maximum homogeneity within groups and maximum heterogeneity among groups. Therefore, this procedure allows the identification of divergent genotypes, i.e., those with contrasting allele frequency for different traits. Divergent genotypes can be recombined via crosses, thus increasing the likelihood of recovering superior genotypes in segregating populations (Maluf \& Ferreira 1983, Cruz et al. 2012).

To subsidize snap bean breeding programs, given the importance of this crop in Brazil, this study aimed at characterizing 29 bush snap bean genotypes from different countries of origin, assessing the genetic divergence among the genotypes evaluated and the extent of phenotypic and genetic variability regarding 12 agro-morphological traits, as well as determining and discriminating the relative importance of these traits for genetic divergence.

\section{MATERIAL AND METHODS}

The experiment was conducted in the field, at the Universidade Estadual de Goiás, in Ipameri, Goiás State, Brazil ( $17^{\circ} 41^{\prime}$ S, $48^{\circ} 11^{\prime} \mathrm{W}$ and $800 \mathrm{~m}$ of altitude), in 2013. According to the Köppen classification, the climate is Aw, with an average temperature of $21.9^{\circ} \mathrm{C}$, average relative humidity of $58-81 \%$ and annual rainfall of $1,447 \mathrm{~mm}$. Approximately $80 \%$ of the rainfall occurs in December, January and March, while the rest is distributed mainly in October, November and February. As a form of general climatic characterization of the region, detailed 
information on average temperatures and monthly water balance are described by Morais Júnior et al. (2012). The soil is classified as a clayey texture Oxisol ("Latossolo Amarelo") (Embrapa 2013).

A randomized complete block design with 29 treatments and four replications was used. The treatments consisted of bush snap bean genotypes from different countries of origin and different qualitative morphological traits, regarding flower color, pod color and pod type (Table 1). The experimental plot had four $2.40 \mathrm{~m}$ rows, with plants arranged in a $0.40 \mathrm{~m} \times 0.15 \mathrm{~m}$ spacing. Green pod data were obtained from the two side rows and seed data from the two central rows.

Sowing took place on May 24 (2013), after the soil had been corrected with dolomitic limestone, considering the acidity, calcium and magnesium levels in the chemical analysis. The soil was fertilized with $1.0 \mathrm{t} \mathrm{ha}^{-1}$ of NPK (5-25-15) at planting and, for cover, $200 \mathrm{~kg} \mathrm{ha}^{-1}$ of urea were applied at 20 days after sowing (Sousa \& Lobato 2004). The water needs of the crop were met through a drip irrigation system and weeds were controlled manually. Due to the high incidence of Diabrotica speciosa (Germar), pyrethroid was sprayed at about $200 \mathrm{ml} \mathrm{ha}^{-1}$.

Twelve agro-morphological quantitative traits were assessed, which are related to the agronomic performance of the crop, yield components, pod morphology and quality (Table 2). Data related to the commercial pod yield, characterized by the typical shape and color of each genotype at the point of harvest, were obtained in two harvests, with an interval of one week. More details on the measurements of each trait are presented by Peixoto et al. (2002).

Analysis of variance (Anova) was performed to obtain adjusted means, Fisher least significant differences between means, quadratic and variance components. The following tests were performed

Table 1. Code, origin and main qualitative morphological traits (flower color, pod color and pod type) of the 29 bush snap bean genotypes evaluated.

\begin{tabular}{clcccc}
\hline Code & \multicolumn{1}{c}{ Genotype } & Flower color & Pod color & Pod type & Origin ${ }^{(1)}$ \\
\hline 1 & Amarelo Japonês & White & Green & Cylindrical & Japan \\
2 & Blue Lake 274 & White & Green & Cylindrical & USA \\
3 & Branco Japonês & White & Green & Cylindrical & Japan \\
4 & Cherokee Wax & Purple & Yellow & Flat & USA \\
5 & Commodore Improved & White & Green & Cylindrical & USA \\
6 & Contender & Purple & Green & Cylindrical & USA \\
7 & Delinel & White & Green & Cylindrical & USA \\
8 & Derby & White & Green & Cylindrical & USA \\
9 & Espada & White & Green & Cylindrical & USA \\
10 & Festina & White & Green & Cylindrical & USA \\
11 & Gold Rush & White & Yellow & Cylindrical & USA \\
12 & Improved Gold Wash & Yellow & Yellow & Cylindrical & USA \\
13 & Jade & White & Green & Cylindrical & USA \\
14 & Kentucky Wonder Bush & White & Green & Cylindrical & USA \\
15 & Line Hab 1 & White & Green & Cylindrical & CIAT \\
16 & Line Hab 39 & White & Green & Cylindrical & CIAT \\
17 & Line Hab 46 46 & Green & Cylindrical & CIAT \\
18 & Maxibel & White & Green & Cylindrical & USA \\
19 & Provider & White & Green & Cylindrical & USA \\
20 & Purple Queen & White & Purple & Cylindrical & USA \\
21 & Rocdor & Purple & Yellow & Flat & USA \\
22 & Royal Burgundy & Yellow & Purple & Flat & USA \\
23 & Slenderwash & Purple & Yellow & Cylindrical & USA \\
24 & Strike & White & Green & Cylindrical & USA \\
25 & Stringless Green & White & Green & Flat & USA \\
26 & Tenderette & White & Green & Flat & USA \\
27 & Tendergreen & Phite & Green & Cylindrical & USA \\
28 & Tendergreen Improved & White & Green & Cylindrical & USA \\
29 & Turmalina & White & Green & Flat & Brazil \\
\hline
\end{tabular}

(1) CIAT: International Center for Tropical Agriculture, Colombia. 
Table 2. Twelve agro-morphological quantitative traits assessed in bush snap bean genotypes, their code and measurement method.

\begin{tabular}{|c|c|c|}
\hline Code & Trait & Measurement method \\
\hline PVI & Plant vigor (score) & $\begin{array}{l}\text { Visual assessment at flowering, by rating scale ( } 1-5 \text { scale, } \\
\text { with regular intervals of } 0.5 \text {, where } 1 \text { is the worst and } 5 \text { the best) }\end{array}$ \\
\hline PLE & Pod length $(\mathrm{cm})$ & Average longitudinal length of 10 pods, using a graduated ruler \\
\hline PDI & Pod diameter $(\mathrm{cm})$ & Average cross section of 10 pods, using a digital caliper \\
\hline $\mathrm{CPA}$ & Commercial pods aspect (score) & $\begin{array}{l}\text { Visual assessment at harvest, by rating scale ( } 1-5 \text { scale, } \\
\text { with regular intervals of } 0.5 \text {, where } 1 \text { is the worst and } 5 \text { the best) }\end{array}$ \\
\hline PWE & Pod weight $(\mathrm{kg})$ & Average weight of all pods per plot, using a scale \\
\hline $\mathrm{NCP}$ & Number of commercial pods per plant (unit) & Average number of all commercial pods in all plants \\
\hline HSW & 100 -seed weight $(\mathrm{g})$ & Average weight of 100 harvested seeds \\
\hline $\mathrm{PHH}$ & Plant height at harvest $(\mathrm{cm})$ & Average distance from the base to the end of the main stem at harvest \\
\hline NMP & Number of mature pods per plant (unit) & Average number of all mature pods in all plants of the plot area \\
\hline NSP & Number of seeds per pod (unit) & Average number of seeds formed in 10 pods \\
\hline SYI & Seed yield $(\mathrm{t} \mathrm{ha-1})$ & Ratio between the average weight of all seeds and the plot area \\
\hline CPY & Commercial pods yield $\left(\mathrm{kg} \mathrm{ha}^{-1}\right)$ & Ratio between the average weight of all commercial pods and the plot area \\
\hline
\end{tabular}

to evaluate the Anova assumptions: Shapiro-Wilk's test to check the normal distribution of the residuals; Levene's test for homogeneity of variances; Tukey's test for nonadditivity; and graphical analysis for independence of the residuals. Anova was performed by fitting a fixed linear model, according to the experimental design. The following parameters were estimated for each trait: error variance between plots; quadratic component of treatment; coefficient of genetic determination; selective accuracy (Resende \& Duarte 2007); experimental, genotypic and relative coefficient of variation (Vencovsky \& Barriga 1992).

To assess the associations between traits, genetic and phenotypic correlation coefficients were calculated between all pairs of traits (Steel \& Torrie 1980). The genetic and phenotypic (co)variance matrices between the traits were calculated after estimating the sum of squares and products matrices for treatment $(\mathrm{H})$ and the error $(\mathrm{E})$, and their respective degrees of freedom, using multivariate analysis of variance (Manova).

The relative contribution of each trait to the genetic diversity was determined by the Singh's method (Singh 1981). To assess the genetic divergence between genotypes, based on traits, multivariate analysis was performed using the following clustering techniques: UPGMA (Sneath \& Sokal 1973) and Tocher optimization (Rao 1952). Both methods were based on generalized Mahalanobis distance $\mathrm{D}^{2}$ (Mahalanobis 1936), used as a dissimilarity measure, and the technique of canonical variables.

The magnitude of the adjustment between the distance matrix and cluster analysis (UPGMA and
Tocher) was estimated by cophenetic correlation (Sokal \& Rohlf 1962). The Mantel's randomization test (Mantel 1967) was applied, based on 10,000 permutations of rows and columns of the cophenetic matrix of each clustering method, to test the hypothesis of a null correlation between the cophenetic matrix and the original distance matrix. The Pearson's correlation coefficient between the adjusted means of the genotypes, for each trait, and the scores of the main canonical variables that explain at least $80 \%$ of the total variation were also estimated. The Student $t$-test was used to measure the significance of the Pearson's correlation coefficient. All operations and statistical analyses were performed using the R platform (R Core Team 2016). The following packages were used: "manova", "stats", "biotools", "Morpho", "ggdendro" and "scatterplot3d".

\section{RESULTS AND DISCUSSION}

The averages, residual and genetic parameters for each agro-morphological trait are shown in Table 3. Based on the estimates of selective accuracy (Acc), moderate to high experimental precision was detected for the traits. This statistics is suitable as a measure of precision in the selections (Resende \& Duarte 2007). According to Steel \& Torrie (1980), the ideal selective accuracy must be $\geq 90 \%$, which corresponds to the values detected for most traits assessed in this study.

Genetic variability is a prerequisite for the efficient identification of superior genotypes. Therefore, it is essential to partition the phenotypic 
Table 3. Estimates of residual and genetic parameters for agro-morphological traits assessed in bush snap bean genotypes: residual mean square $\left(\mathrm{MS}_{\mathrm{e}}\right)$, genotype quadratic component $\left(\varphi_{\mathrm{g}}\right)$, coefficient of genetic determination $\left(\mathrm{R}^{2}\right)$, selective accuracy (Acc), general average $(\bar{X})$, experimental coefficient of variation $\left(\mathrm{CV}_{\mathrm{e}}\right)$, genetic coefficient of variation $\left(\mathrm{CV}_{\mathrm{g}}\right)$ and relative coefficient of variation $\left(\mathrm{CV}_{\mathrm{r}}\right)$.

\begin{tabular}{lrrrrrrrr}
\hline Trait $^{(1)}$ & $\mathrm{MS}_{\mathrm{e}}$ & $\varphi_{\mathrm{g}}$ & $\mathrm{R}^{2}$ & $\mathrm{Acc}$ & $\overline{\mathrm{X}}$ & $\mathrm{CV}_{\mathrm{e}}(\%)$ & $\mathrm{CV}_{\mathrm{g}}(\%)$ & $\mathrm{CV}_{\mathrm{r}}(\%)$ \\
\hline PVI & 0.19 & 0.10 & 0.68 & 0.82 & 3.57 & 12.27 & 8.91 & 0.73 \\
PLE & 0.81 & 1.12 & 0.85 & 0.92 & 14.75 & 6.10 & 7.18 & 1.18 \\
PDI & 0.67 & 0.13 & 0.44 & 0.66 & 7.66 & 10.65 & 4.72 & 0.44 \\
CPA & 0.07 & 0.44 & 0.96 & 0.98 & 3.45 & 7.81 & 19.26 & 2.47 \\
PWE & 0.43 & 1.26 & 0.92 & 0.96 & 7.63 & 8.59 & 14.70 & 1.71 \\
NCP & 19.70 & 14.46 & 0.75 & 0.86 & 18.07 & 24.59 & 21.04 & 0.86 \\
HSW & 1.77 & 38.20 & 0.99 & 0.99 & 31.34 & 4.25 & 19.72 & 4.64 \\
PHH & 9.72 & 31.42 & 0.93 & 0.96 & 54.91 & 5.68 & 10.21 & 1.80 \\
NMP & 14.90 & 8.01 & 0.68 & 0.83 & 15.81 & 24.48 & 17.91 & 0.73 \\
NSP & 0.19 & 0.03 & 0.41 & 0.64 & 5.84 & 7.56 & 3.12 & 0.41 \\
SYI & 0.14 & 0.17 & 0.83 & 0.91 & 2.62 & 14.24 & 15.59 & 1.09 \\
CPY & 3.30 & 11.06 & 0.99 & 0.96 & 11.85 & 15.32 & 28.06 & 1.83 \\
\hline
\end{tabular}

(1) PVI: plant vigor; PLE: pod length (cm); PDI: pod diameter (cm); CPA: commercial pod aspect; PWE: pod weight (kg); NCP: number of commercial pods per plant; HSW: 100-seed weight (g); PHH: plant height at harvest $(\mathrm{cm})$; NMP: number of mature pods per plant; NSP: number of seeds per pod; SYI: seed yield (t ha $\left.{ }^{-1}\right)$; CPY: commercial pod yield $\left(\mathrm{kg} \mathrm{ha}^{-1}\right)$.

variability into its genetic and non-genetic components (Vencovsky \& Barriga 1992). A high coefficient of genetic determination $\left(\mathrm{R}^{2}\right)$ was detected for most traits, especially for 100 -seed weight, commercial pod yield and commercial pod aspect, which presented values greater than 0.95 (Table 3). Regarding the relative coefficient of variation $\left(\mathrm{CV}_{\mathrm{r}}\right)$, most traits presented values higher than the unit (1), especially for 100 -seed weight, commercial pod aspect, commercial pod yield, plant height at harvest and pod weight, with values greater than 1.5. Therefore, these results suggest a favorable condition to identify superior genotypes, with respect to these traits, either for direct use in commercial production or as new parents in breeding programs.

The adjusted means of the genotypes and the Fisher least significant difference statistics, for each agro-morphological trait, are shown in Table 4. Significant differences $(p \leq 0.05)$ were detected between the genotypes for all traits assessed. The Delinel and Maxibel cultivars showed the best commercial pod aspect, while the Blue Lake 274, Purple Queen and Tendergreen Improved cultivars showed the worst scores for this trait. Although the commercial pod aspect is an important trait in snap beans, the number of commercial pods per plant is a trait more directly associated with the effective pod yield, i.e., the commercial pod yield, because of their high genetic correlation (Table 7). Regarding the genotypes with higher commercial pod yield, the Contender, Jade and Provider cultivars were the most productive (approximately $18 \mathrm{t} \mathrm{ha}^{-1}$ ) and statistically different $(p \leq 0.05)$ from the others. Therefore, among the genotypes assessed, these cultivars are the most promising for commercial production in the Ipameri region, because of their acceptable values for other traits, such as medium to high plant vigor (Table 4). However, for the safe recommendation of these cultivars, on a commercial scale, further studies should be carried out to evaluate the yield adaptability and stability over the years and other environments.

The Contender cultivar presented the highest adjusted average for 100-seed weight and pod weight, statistically different $(\mathrm{p} \leq 0.05)$ from the others (Table 4). In addition, this cultivar is among those with larger pod length and diameter and lower number of seeds per plant. Although this cultivar has larger seeds, the pods present good commercial pod aspect, conferred by its bigger, cylindrical pods (Table 1). This is an interesting characteristic, since large seeds are usually an undesirable feature in snap bean cultivars, because of the presence of protrusions on the pod surface, which confer a strange appearance (Peixoto et al. 2002). A potentially greater plant vigor is another characteristic of the Contender cultivar, since this trait is positively correlated with 100-seed weight (Table 5). Larger seeds have higher seed reserve content, an important feature in legumes (Henning et al. 2010). Genotypes with greater plant vigor are desirable, because of their better initial agronomic performance in the field. Therefore, because of its high effective pod yield 
Table 4. Adjusted averages of 29 bush snap bean genotypes for the 12 traits assessed and basic statistics associated with the analysis of variance.

\begin{tabular}{|c|c|c|c|c|c|c|c|c|c|c|c|c|}
\hline Genotype & $\mathrm{PVI}^{(1)}$ & PLE & PDI & $\mathrm{CPA}$ & PWE & NCP & HSW & PHH & NMP & NSP & SYI & CPY \\
\hline Amarelo Japonês & 3.8 & 15 & 6.7 & 4.3 & 8.3 & 21 & 31 & 64 & 15 & 6.4 & 3.0 & 14 \\
\hline Blue Lake 274 & 3.3 & 14 & 7.8 & 2.3 & 6.9 & 15 & 35 & 48 & 12 & 5.3 & 2.0 & 8 \\
\hline Branco Japonês & 3.9 & 15 & 7.6 & 3.8 & 8.1 & 17 & 30 & 57 & 13 & 5.7 & 2.6 & 12 \\
\hline Cherokee Wax & 3.4 & 15 & 6.7 & 3.3 & 7.5 & 12 & 45 & 59 & 14 & 5.7 & 2.4 & 7 \\
\hline Commodore Improved & 4.0 & 15 & 7.9 & 2.9 & 7.1 & 22 & 31 & 51 & 18 & 5.7 & 3.2 & 15 \\
\hline Contender & 3.5 & 17 & 8.3 & 4.4 & 11.1 & 21 & 47 & 51 & 14 & 5.1 & 3.0 & 18 \\
\hline Delinel & 3.6 & 17 & 8.3 & 4.8 & 6.9 & 21 & 23 & 58 & 17 & 5.7 & 2.6 & 15 \\
\hline Derby & 3.5 & 15 & 8.2 & 2.8 & 8.5 & 11 & 30 & 65 & 20 & 5.9 & 3.1 & 6 \\
\hline Espada & 3.8 & 14 & 7.3 & 2.5 & 6.5 & 22 & 26 & 49 & 17 & 5.7 & 2.2 & 11 \\
\hline Festina & 3.4 & 14 & 7.4 & 3.3 & 6.6 & 16 & 31 & 48 & 19 & 6.0 & 3.0 & 12 \\
\hline Gold Rush & 2.9 & 15 & 8.3 & 3.8 & 8.0 & 13 & 23 & 51 & 22 & 6.0 & 2.3 & 7 \\
\hline Improved Gold Wash & 3.1 & 13 & 7.2 & 4.0 & 7.7 & 23 & 34 & 55 & 19 & 5.5 & 2.7 & 13 \\
\hline Jade & 3.6 & 15 & 7.5 & 4.0 & 5.4 & 26 & 29 & 54 & 16 & 6.1 & 2.9 & 18 \\
\hline Kentucky Wonder Bush & 3.6 & 14 & 7.4 & 3.8 & 8.2 & 13 & 29 & 66 & 18 & 5.9 & 2.4 & 9 \\
\hline Line Hab 1 & 3.5 & 16 & 8.3 & 3.9 & 9.4 & 15 & 35 & 63 & 15 & 6.3 & 2.5 & 10 \\
\hline Line Hab 39 & 3.4 & 14 & 7.6 & 3.4 & 7.0 & 17 & 35 & 55 & 13 & 5.8 & 2.8 & 13 \\
\hline Line Hab 46 & 3.9 & 14 & 8.3 & 2.8 & 8.4 & 16 & 35 & 59 & 10 & 6.1 & 2.7 & 11 \\
\hline Maxibel & 3.5 & 18 & 7.4 & 4.8 & 6.3 & 21 & 21 & 61 & 16 & 5.8 & 1.9 & 12 \\
\hline Provider & 3.4 & 14 & 7.5 & 3.9 & 9.3 & 20 & 21 & 54 & 15 & 6.0 & 1.5 & 18 \\
\hline Purple Queen & 4.0 & 13 & 7.0 & 2.4 & 6.4 & 13 & 32 & 62 & 17 & 5.8 & 2.7 & 9 \\
\hline Rocdor & 3.5 & 15 & 8.2 & 3.4 & 7.2 & 18 & 30 & 47 & 11 & 6.5 & 2.1 & 10 \\
\hline Royal Burgundy & 4.3 & 14 & 7.2 & 3.9 & 7.8 & 14 & 33 & 57 & 12 & 5.7 & 2.1 & 10 \\
\hline Slenderwash & 2.9 & 13 & 8.3 & 3.4 & 5.9 & 25 & 24 & 45 & 22 & 5.7 & 2.3 & 11 \\
\hline Strike & 3.1 & 15 & 7.1 & 3.3 & 7.7 & 28 & 27 & 52 & 20 & 5.7 & 3.4 & 16 \\
\hline Stringless Green & 4.6 & 14 & 8.3 & 3.4 & 8.4 & 19 & 41 & 46 & 11 & 6.0 & 3.3 & 15 \\
\hline Tenderette & 3.9 & 14 & 7.0 & 3.0 & 6.9 & 18 & 34 & 55 & 22 & 5.9 & 2.8 & 11 \\
\hline Tendergreen & 3.8 & 15 & 8.6 & 3.1 & 8.4 & 18 & 36 & 57 & 16 & 5.9 & 2.5 & 11 \\
\hline Tendergreen Improved & 3.5 & 15 & 7.6 & 2.4 & 7.3 & 14 & 30 & 54 & 13 & 5.9 & 2.9 & 14 \\
\hline Turmalina & 3.1 & 16 & 7.7 & 3.9 & 8.5 & 15 & 33 & 52 & 12 & 5.9 & 2.9 & 11 \\
\hline $\operatorname{LSD}(0.05)$ & 0.6 & 1.3 & 1.1 & 0.4 & 0.9 & 6.2 & 1.9 & 4.4 & 5.4 & 0.6 & 0.5 & 2.6 \\
\hline
\end{tabular}

(1) PVI: plant vigor; PLE: pod length (cm); PDI: pod diameter (cm); CPA: commercial pod aspect; PWE: pod weight (kg); NCP: number of commercial pods per plant; HSW: 100-seed weight (g); PHH: plant height at harvest (cm); NMP: number of mature pods per plant; NSP: number of seeds per pod; SYI: seed yield (t ha-1); CPY: commercial pod yield $\left(\mathrm{kg} \mathrm{ha}^{-1}\right)$. $\mathrm{LSD}_{(0.05)}$ : Fisher least significant difference at $5 \%$; SE: standard error; SD: standard deviation.

Table 5. Phenotypic (above diagonal) and genetic (below diagonal) correlation between traits assessed in bush snap bean genotypes.

\begin{tabular}{lcccccccccccc}
\hline Trait $^{(1)}$ & PVI & PLE & PDI & CPA & PWE & NCP & HSW & PHH & NMP & NSP & SYI & CPY \\
\hline PVI & - & -0.03 & -0.03 & -0.19 & 0.06 & -0.19 & $0.35^{*}$ & 0.13 & $-0.31^{*}$ & 0.13 & 0.26 & 0.11 \\
PLE & -0.11 & - & 0.16 & $0.59 * *$ & 0.29 & 0.04 & 0.01 & $0.32^{*}$ & -0.18 & -0.04 & -0.07 & 0.22 \\
PDI & -0.13 & 0.05 & - & -0.01 & 0.29 & -0.10 & 0.15 & -0.20 & -0.22 & -0.06 & -0.05 & -0.06 \\
CPA & -0.23 & $0.65^{* *}$ & -0.01 & - & 0.22 & 0.26 & -0.16 & 0.22 & 0.00 & 0.00 & -0.22 & $0.37 *$ \\
PWE & 0.06 & $0.32^{*}$ & $0.50^{* *}$ & & - & -0.29 & $0.49 * *$ & 0.19 & $-0.33^{*}$ & -0.06 & 0.06 & 0.16 \\
NCP & -0.18 & 0.11 & -0.19 & 0.24 & $-0.34^{*}$ & - & $-0.31^{*}$ & $-0.37 *$ & $0.34^{*}$ & -0.11 & 0.13 & $0.77 * *$ \\
HSW & $0.43^{*}$ & 0.01 & 0.23 & 0.30 & $0.51^{* *}$ & $-0.37^{*}$ & - & -0.05 & $-0.43^{* *}$ & -0.21 & $0.45^{* *}$ & -0.01 \\
PHH & 0.15 & $0.36^{*}$ & $-0.31^{*}$ & -0.16 & 0.22 & $-0.43^{* *}$ & -0.05 & - & -0.04 & 0.27 & -0.14 & -0.25 \\
NMP & $-0.40^{*}$ & -0.22 & $-0.42^{*}$ & 0.24 & $-0.39^{*}$ & $0.46^{* *}$ & $-0.55^{* *}$ & -0.11 & - & -0.04 & 0.09 & -0.11 \\
NSP & $0.33^{*}$ & -0.10 & -0.11 & -0.02 & -0.10 & -0.15 & $-0.34^{*}$ & $0.39 *$ & -0.11 & - & -0.03 & -0.18 \\
SYI & 0.29 & -0.11 & -0.15 & 0.00 & 0.07 & 0.18 & $0.49^{* *}$ & -0.18 & 0.04 & -0.12 & - & 0.29 \\
CPY & 0.11 & 0.24 & -0.17 & -0.26 & 0.18 & $0.67 * *$ & -0.02 & -0.25 & -0.12 & -0.15 & 0.22 & - \\
\hline
\end{tabular}

(1) PVI: plant vigor; PLE: pod length (cm); PDI: pod diameter (cm); CPA: commercial pod aspect; PWE: pod weight (kg); NCP: number of commercial pods per plant; HSW: 100-seed weight (g); PHH: plant height at harvest $(\mathrm{cm})$; NMP: number of mature pods per plant; NSP: number of seeds per pod; SYI: seed yield (t ha-1); CPY: commercial pod yield $\left(\mathrm{kg} \mathrm{ha}^{-1}\right){ }^{* *}$, *: significant for $\mathrm{p} \leq 0.01$ and $\mathrm{p} \leq 0.05$, respectively, according to the Student's t-test. 
and pods with good commercial quality, including succulent green pod wall, the Contender cultivar could be recommended for use by regional producers or in crosses to generate promising segregating populations.

Using the squared Mahalanobis distance (D2ii'), the 29 genotypes were grouped into four clusters, either by the Tocher optimization method (Table 6) or the UPGMA method (Figure 1). This equivalence in clustering genotypes by the methods is an evidence of a high consistency in the results, also supported by the high estimates of the cophenetic correlation coefficient (Tocher's method: 0.83; UPGMA: 0.72$)$, both significant $(p<0.001)$ by

Table 6. Average distance, within (diagonal) and between (off-diagonal) clusters, among the four clusters determined by the Tocher optimization method, based on the generalized Mahalanobis distance $\left(\mathrm{D}^{2}{ }_{\mathrm{ii}}\right)$.

\begin{tabular}{|c|c|c|c|c|c|c|}
\hline Cluster & $\mathrm{I}$ & II & III & IV & Number of genotypes & Genotype \\
\hline I & 51.5 & 112.7 & 120.2 & 247.4 & 23 & $\begin{array}{l}\text { Line Hab 46, Tendergreen, Line Hab 39, Tenderette, } \\
\text { Royal Burgundy, Branco Japonês, Improved Gold Wash, } \\
\text { Turmalina, Commodore Improved, Festina, Rocdor, } \\
\text { Tendergreen Improved, Purple Queen, Strike, Kentucky } \\
\text { Wonder Bush, Line Hab 1, Derby, Amarelo Japonês, } \\
\text { Jade, Blue Lake 274, Espada, Slenderwash, Gold Rush }\end{array}$ \\
\hline II & & 45.1 & 296.1 & 398.8 & 3 & Delinel, Maxibel, Provider \\
\hline III & & & 62.1 & 96.6 & 2 & Cherokee Wax, Stringless Green \\
\hline IV & & & & 0 & 1 & Contender \\
\hline
\end{tabular}

Cophenetic correlation coefficient: 0.83 ( $\mathrm{p}<0.001$ by the Mantel test).

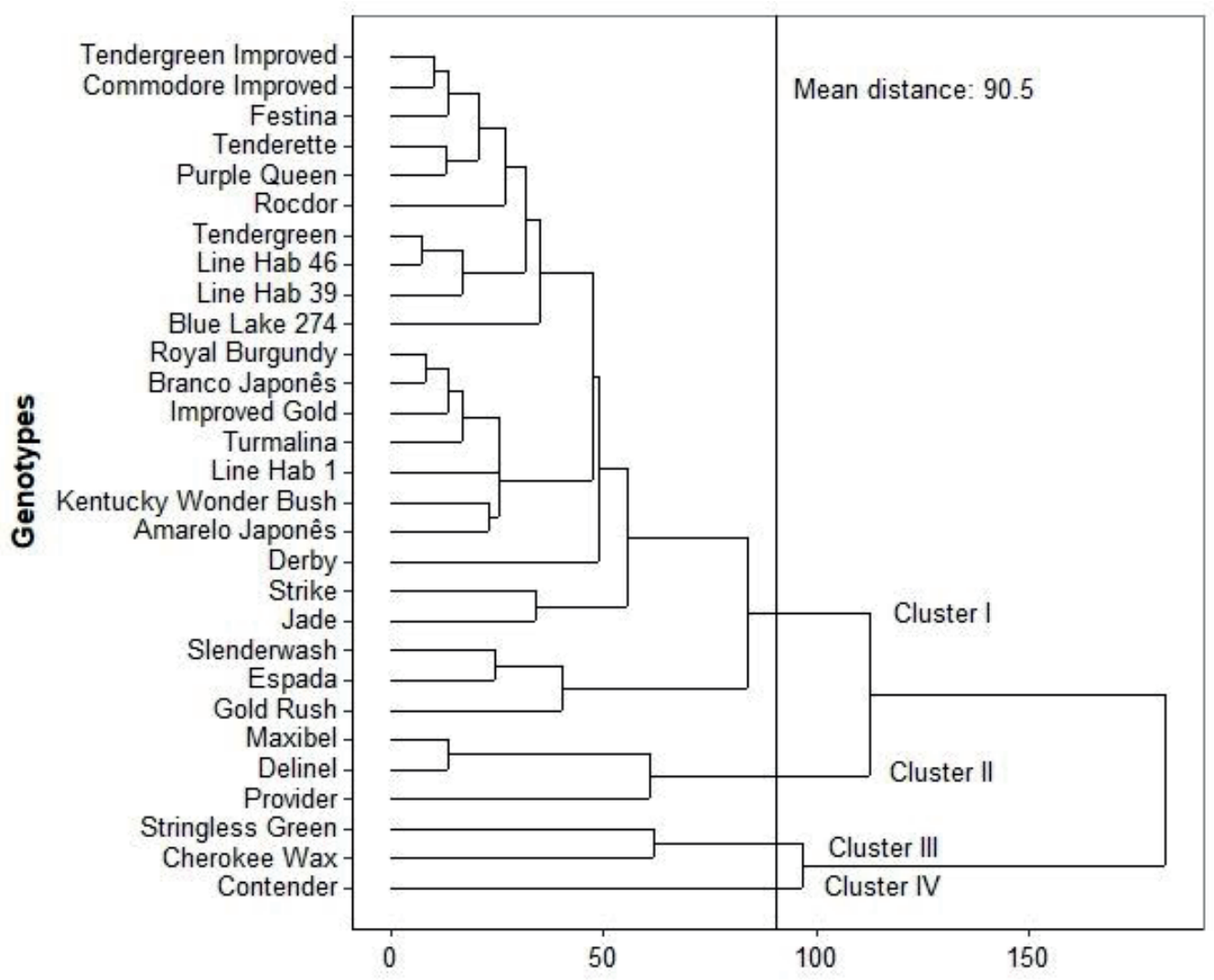

Figure 1. Generalized Mahalanobis distances $\left(\mathrm{D}^{2}{ }_{\mathrm{ii}}\right)$ dendrogram based on the UPGMA clustering of 29 bush snap bean genotypes for the 12 traits assessed. Cophenetic correlation coefficient: $0.72(\mathrm{p}<0.001$ by the Mantel test). 
the Mantel test. As expected, a lower estimate of cophenetic correlation was detected for the UPGMA method, given that the cophenetic distances obtained by the Tocher method reliably synthesize the original generalized Mahalanobis distance. Furthermore, hierarchical methods, such as UPGMA, typically exhibit weaker linear association, resulting in a distortion of the cophenetic distances (Silva \& Dias 2013). These results indicate that there is a high genetic divergence between some of the genotypes assessed, because, although the great majority of the genotypes are grouped with less than 50 units of distance (e.g., clusters I), the clusters diverged from each other in distances of about 100 units or more.

Based on the results of clustering, possible crosses between the genotypes allocated to cluster I, about $79.3 \%$ from the total (Table 6), would tend to decrease the probability of obtaining more promising segregating populations. The largest generalized Mahalanobis distance was observed between clusters II and IV (398.8), and clusters II and III (296.1), indicating the importance of the genotypes allocated to cluster II (Delinel, Maxibel and Provider cultivars), as a source of parents for promising crosses. However, it is important to note that the clustering data alone is not the best strategy for defining crosses, since genetically distinct genotypes do not necessarily have the best combining ability. Therefore, crosses between the best genotype from cluster II and the Contender cultivar, single genotype from cluster IV, could be more interesting to the breeding program. According to Cruz et al. (2012), provided that the genotypes have high additive value, i.e., high average for the interesting traits, the use of the most contrasting ones should be considered for crosses. This type of cross can increase the probability to complement different but favorable alleles, increasing their frequency in superior genotypes.

The canonical variable analysis explained $82.45 \%$ of the total variation by the first three canonical variables (Figure 2). The dispersion of the scores of genotypes in the space of the first three canonical variables showed the formation of about four clusters, also detected by the Tocher optimization and UPGMA methods. As previously observed, the Contender cultivar (code 6), a single constituent of cluster IV, was the most divergent to the other clusters, especially for pod weight, 100-seed weight and commercial pod yield (Table 6). Based on the absolute generalized Mahalanobis distances (Dii', data not shown), the six pairs of genotypes with the largest distance values, in decreasing order, were: Contender x Slenderwash, Contender x Gold Rush, Contender x Espada, Contender x Delinel, Maxibel x Stringless Green and Contender x Derby. Therefore, the exploitation of the genetic variability released with such crosses may contribute to the selection of more transgressive genotypes (Rahman et al. 2002, Cruz et al. 2012).

The relative contribution of each trait to the genetic dissimilarity, according to the method by Singh (1981), showed that two of these traits contributed with $64.45 \%$ of genetic divergence between the genotypes (Table 7). These traits were 100 -seed weight, contributing with $47.25 \%$, and commercial pod aspect, with $17.2 \%$, indicating the existence of expressive genetic variability for these traits, as previously described (Table 3 ). These traits were more efficient in explaining the dissimilarity among genotypes and, therefore, should be prioritized when choosing parents in breeding programs. The commercial pod yield, although it has also shown a great amplitude (6-18 $\mathrm{t} \mathrm{ha}^{-1}$ ) (Table 4), had a small contribution to divergence, with $7.58 \%$, being the fourth in importance. Despite this result, this trait is important for breeding, since the selection of parents with higher commercial pod yield in crosses will result in a greater probability of obtaining superior lines.

To assess the magnitude of the canonical variables expressed for each trait, correlation

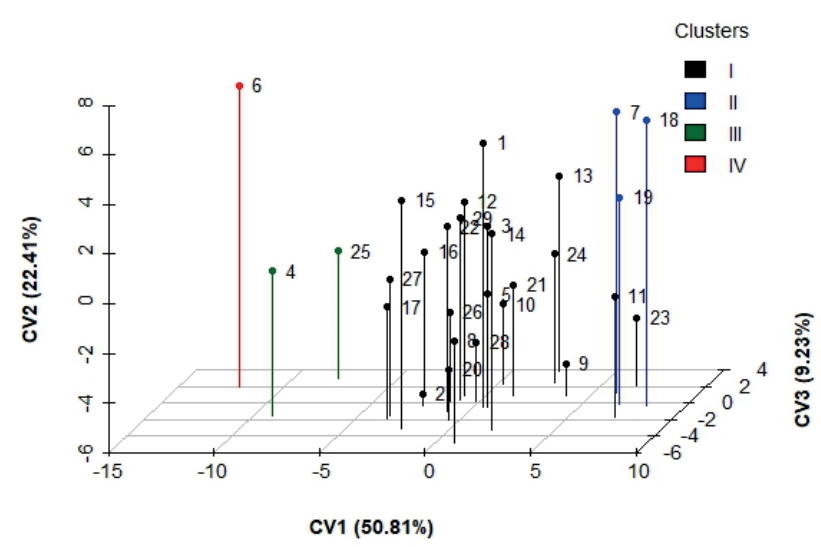

Figure 2. Three-dimensional dispersion of 29 bush snap bean genotypes, in relation to the first three canonical variables (CV1, CV2 and CV3) for the traits assessed. Codes for clusters were determined previously by the Tocher method. Genotype codes are according to Table 1. 
Table 7. Relative contribution (S.j) and accumulated relative contribution (Accumulated S.j) of the 12 traits assessed for genetic divergence, estimated by the Singh's method (1981), and coefficient of correlation between the 12 traits and the four main canonical variables (CVi) that explained more than $80 \%$ of the total variation for the traits assessed.

\begin{tabular}{lcccccc}
\hline \multirow{2}{*}{ Trait $^{(1)}$} & \multicolumn{3}{c}{ Singh statistics } & \multicolumn{3}{c}{ Canonical variables (CVi) } \\
\cline { 2 - 7 } & S.j (\%) & Accumulated S.j (\%) & CV1 & CV2 & CV3 & CV4 \\
\hline HSW & 47.25 & 47.25 & $-0.99^{* *}$ & 0.01 & -0.02 & -0.02 \\
CPA & 17.20 & 64.45 & $0.19^{*}$ & $0.91^{* *}$ & $0.16^{*}$ & 0.04 \\
PHH & 8.10 & 72.55 & 0.02 & $0.40^{* *}$ & $-0.72^{* *}$ & -0.42 \\
CPY & 7.58 & 80.13 & 0.00 & $0.41^{* *}$ & $0.65^{* *}$ & 0.13 \\
PWE & 5.43 & 85.56 & $-0.42^{* *}$ & $0.41^{* *}$ & $-0.32^{* *}$ & $0.66^{* *}$ \\
PLE & 4.16 & 89.73 & 0.00 & $0.58^{* *}$ & -0.06 & -0.02 \\
SYI & 3.18 & 92.90 & $-0.33^{* *}$ & -0.06 & $0.24^{* *}$ & -0.10 \\
PVI & 2.47 & 95.38 & $-0.25^{* *}$ & 0.01 & -0.01 & $-0.28^{* *}$ \\
NMP & 1.58 & 96.95 & $0.31^{* *}$ & -0.10 & -0.03 & 0.00 \\
NSP & 1.13 & 98.09 & $0.17^{*}$ & 0.02 & -0.13 & -0.04 \\
PDI & 0.99 & 99.08 & -0.02 & 0.01 & -0.01 & $0.35^{* *}$ \\
NCP & 0.92 & 100.00 & $0.22^{* *}$ & $0.16^{*}$ & $0.61 *$ & -0.02 \\
\hline
\end{tabular}

(1) PVI: plant vigor; PLE: pod length (cm); PDI: pod diameter (cm); CPA: commercial pod aspect; PWE: pod weight (kg); NCP: number of commercial pods per plant; HSW: 100-seed weight (g); PHH: plant height at harvest $(\mathrm{cm})$; NMP: number of mature pods per plant; NSP: number of seeds per pod; SYI: seed yield $\left(\mathrm{t}\right.$ ha ${ }^{-1}$ ); CPY: commercial pod yield $\left(\mathrm{kg} \mathrm{ha}^{-1}\right){ }^{* *}{ }^{*}$ : significant for $\mathrm{p} \leq 0.01$ and $\mathrm{p} \leq 0.05$, respectively, according to the Student's t-test.

coefficients between the traits and the canonical scores were determined for the first four canonical variables, which explained more than $80 \%$ of the total variation (Table 7). Significant correlations of moderate to high magnitudes indicate the partial contribution of the traits to the total variability (Dias et al. 2009). The first canonical variable (CV1) explained the largest portion of the total variation attributed to 100-seed weight, a trait that contributed the most to genetic divergence. The second variable (CV2) capitalized on much of the variability arising from the commercial pod aspect and the third variable (CV3) explained, in most cases, the plant height at harvest. If compared to the contribution of these traits to the genetic divergence, determined by the Singh's method (1981), there was a strong association between the results. Iezzoni \& Pritts (1991), in a study with principal component analysis, also found that, generally, traits with the largest eigenvalues and highest correlations are more important for the respective component and, therefore, explain the capitalized variation.

An interesting factor to note is the lack of correspondence between the clusters formed and the origin of the genotypes, which come from breeding programs in four different countries (Brazil, Colombia, United States of America and Japan). So, as most the snap bean genotypes from different countries of origin tended to cluster together, similar germplasm may have been shared between countries, possibly due to strong trans-national seed exchange. In the literature, there is some evidence for snap bean ancestry having both Mesoamerican and Andean origins, especially regarding the existence of large seed size variability, which is associated with the phaseolin allele pattern (Myers \& Baggett 1999, Blair et al. 2010). According to these authors, the intense selection pressure for seed size in snap beans, in parallel to the selection for seed types in dry beans, freed the phaseolin alleles to introgress from one genepool to another. Such factors have been responsible for the blurred distinction between the large-seeded Andean and small-seeded Mesoamerican types in snap beans.

Therefore, the association between seed size and centers of domestication, i.e., Andean or Mesoamerican, possibly is the main factor associated with the clustering pattern of the 29 genotypes assessed, in addition to the key importance of the 100 -seed weight for the genetic divergence. Better evidence of this clustering pattern is the phaseolin alleles pattern detected in genotypes already evaluated in other studies, such as Kentucky Wonder and Blue Lake-derived cultivars, belonging to a subgroup within the Mesoamerican genepool (Blair et al. 2010). As observed in this study, such cultivars of smaller seeds were allocated to cluster I (Table 6). On the other hand, the most distant Contender cultivar was allocated to cluster IV, thus possibly belonging to the Andean genepool. 


\section{CONCLUSIONS}

1. The 29 snap bean genotypes exhibited a wide range of variability and differentiation for agronomic and morphological traits, mainly for 100-seed weight, aspect and yield of commercial pods, plant height at harvest and pod weight. Therefore, these traits are favorable for improvement through effective phenotypic selection, where high genetic gain can be achieved;

2. High genetic divergence was detected between the genotypes, in which 100-seed weight and commercial pod aspect were the most important traits for clustering. Some genotypes possess desirable characteristics for these and other traits, given the favorable genetic associations between traits, and hence could be used directly by regional producers or included in crosses for cultivar development;

3. Snap bean genotypes from different countries of origin tend to cluster together, indicating that similar germplasm is shared among different countries, thus suggesting a strong trans-national seed exchange.

\section{REFERENCES}

ARAÚJO, L. C. et al. Contribution of components of production on snap beans yield. Crop Breeding and Applied Biotechnology, v. 12, n. 3, p. 206-210, 2012.

BLAIR, M. W. et al. Extensive diversity and inter-genepool introgression in a world-wide collection of indeterminate snap beans accessions. Theoretical and Applied Genetics, v. 120, n. 7, p. 1381-1391, 2010.

CRUZ, C. D.; REGAZZI, A. J.; CARNEIRO, P. C. S. Modelo biométrico aplicado ao melhoramento genético. Viçosa: UFV, 2012.

DIAS, F. T. C.; SILVA, A. P. M.; BERTINI, C. H. C. M. Genetic divergence in cowpea genotypes with upright growth and early cycle. Crop Breeding and Applied Biotechnology, v. 9, n. 3, p. 253-259, 2009.

EMPRESA BRASILEIRA DE PESQUISA AGROPECUÁRIA (Embrapa). Sistema brasileiro de classificação de solos. 3. ed. Brasília, DF: Embrapa, 2013.

FILGUEIRA, F. A. R. Novo manual de olericultura: agrotecnologia moderna na produção e comercialização de hortaliças. 3. ed. Viçosa: UFV, 2013.

GEPTS, P. et al. Phaseolin-protein variability in wild forms and landraces of the common beans (Phaseolus vulgaris): evidence for multiple center of domestication. Economic Botany, v. 40, n. 4, p. 451-456, 1986.

HENNING, F. A. et al. Composição química e mobilização de reservas em sementes de soja de alto e baixo vigor. Bragantia, v. 69, n. 3, p. 727-734, 2010.

IEZZONI, A. F.; PRITTS, M. P. Applications of principal component analysis to horticultural research. HortScience, v. 26, n. 4, p. 334-338, 1991.

JOHNSON, R. A.; WICHERN, D. W. Applied multivariate statistical analysis. New Jersey: Englewood Cliffs, 1992.

KRAUSE, W. et al. Genetic divergence in snap beans based on agronomic traits and resistance to bacterial wilt. Crop Breeding and Applied Biotechnology, v. 9, n. 3, p. 246-252, 2009.

MAHALANOBIS, P. C. On the generalized distance in statistics. Proceedings of the National Institute of Sciences of India, v. 2, n. 1, p. 49-55, 1936.

MALUF, W. R.; FERREIRA, P. E. Análise multivariada da divergência genética em feijão-de-vagem (Phaseolus vulgaris L.). Horticultura Brasileira, v. 1, n. 2, p. 31-34, 1983.

MANTEL, N. The detection of disease clustering and a generalized regression approach. Cancer Research, v. 27, n. 2, p. 209-220, 1967.

MORAIS JÚNIOR, O. P. et al. Desempenho de cultivares de couve-flor de verão em Ipameri. Ciência Rural, v. 42, n. 11, p. 1923-1928, 2012.

MYERS, J. R.; BAGGETT, J. R. Improvement of snap beans. In: SINGH, S. (Ed.). Common bean improvement for the 21st century. Boston: Kluwer, 1999. p. 289-329.

PEIXOTO, N. et al. Características agronômicas, produtividade, qualidade de vagens e divergência genética em feijão-vagem de crescimento indeterminado. Horticultura Brasileira, v. 20, n. 3, p. 447-451, 2002.

PEIXOTO, N.; CARDOSO, A. I. I. Cultura do feijãovagem. In: NASCIMENTO, W. M. (Ed.). Hortaliças leguminosas. Brasília, DF: Embrapa, 2016. p. 102-126.

R CORE TEAM. $R$ : a language and environment for statistical computing. Vienna: R Foundation for Statistical Computing, 2016.

RAHMAN, M.; HUSSAIN, D.; ZAFAR, Y. Estimation of genetic divergence among elite cotton cultivars-genotypes by DNA fingerprinting technology. Crop Science, v. 42, n. 6, p. 2137-2144, 2002.

RAO, R. C. Advanced statistical methods in biometric research. New York: John Wiley \& Sons, 1952. 
RESENDE, M. D. V.; DUARTE, J. B. Precisão e controle de qualidade em experimentos de avaliação de cultivares. Pesquisa Agropecuária Tropical, v. 37, n. 3, p. 182-194, 2007.

SILVA, A. R. D.; DIAS, C. T. D. S. A cophenetic correlation coefficient for Tocher's method. Pesquisa Agropecuária Brasileira, v. 48, n. 6, p. 589-596, 2013.

SINGH, D. The relative importance of characters affecting genetic divergence. Indian Journal of Genetics \& Plant Breeding, v. 41, n. 2, p. 237-245, 1981.

SNEATH, I. H. A.; SOKAL, R. R. Numerical taxonomy. San Francisco: Freeman and Company, 1973.
SOKAL, R. R.; ROHLF, F. J. The comparison of dendrograms by objective methods. Taxon, v. 11, n. 2, p. 30-40, 1962.

SOUSA, D. M. G.; LOBATO, E. Cerrado: correção do solo e adubação. 2. ed. Brasília, DF: Embrapa Cerrados, 2004.

STEEL, R. G. D.; TORRIE, J. H. Principles and procedures of statistics: a biometrical approach. 2. ed. New York: McGraw Hill, 1980.

VENCOVSKY, R.; BARRIGA, P. Genética biométrica no fitomelhoramento. Ribeirão Preto: Sociedade Brasileira de Genética, 1992. 